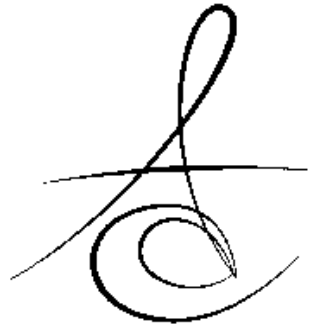

Makale Kodu/Article code: 1969

Makale Gönderilme tarihi: 14.11.2014

Kabul Tarihi: 01.12.2014

\section{AESTHETICS AND FUNCTIONAL REHABILITATION OF AMELOGENESIS IMPERFECTA: 4-YEAR FOLLOW UP.}

\section{AMELOGENESİS İMPERFEKTALİ BİR HASTANİN ESTETİK VE FONKSIYYONEL REHABİLİTASYONU: 4 YİLLİK TAKİP}

\author{
Yrd. Doç. Dr. Ömer KİRMALI**
}

Arş. Gör. Turan SEKMEN*

\section{ABSTRACT}

Amelogenesis imperfecta (AI) is a set of hereditary defects representing the development and clinical appearance of enamel without the presence of whole body symptoms. An esthetic and functional approach must be aspired for these patients to improve the life quality. There was various type of AI and they can be cause of defects on multiple teeth and skeletal malocclusion. Teeth extraction, endodontic treatment of remaining teeth before post and core restorations, esthetic and functional crown lengthening, fixed dental prostheses are include the rehabilitation. This article represents, a patient referred to our clinic suffering from AI who overcame the esthetical and functional problems by receiving multidisciplinary team rehabilitation and must be monitored at periodically for ensuring long-term success to the restorations.

Keywords: amelogenesis imperfecta, aesthetics, zirconium oxide

\section{INTRODUCTION}

AI is a genetically heredities disease which affects structure and clinical appearance of enamel. But, the molecular basis of AI is not exactly understood because of the some mutations in amelogenein (AMEL $X$ ) gene have been identified in people with X-linked and autosomal forms of AI. ${ }^{1,2}$ The main types of AI are correlated with defects in the enamel synthesis process and has been classified into three groups, based on clinical and radiographic features, histologic and mode of inheritance; hypoplastic, hypocalcification and hypomaturation type. ${ }^{3-5}$ In the hypoplastic type, the enamel does not develop to its normal thickness and it appears to be hard and shiny. The hypomaturation type seems some

\section{ÖZET}

Amelogenesis imperfecta (AI) kalıtımsal bozuklukların gelişimini temsil eden ve klinik olarak mine varlığının tamamlanamadığı bir vücut semptomları dizisidir. Bu hastaların yaşam kalitesini arttırmak için estetik ve fonksiyonel bir yaklaşım düşünülmelidir. Çeşitli AI tipleri vardır; bunlar birden çok diş ve iskeletsel maloklüzyon bozukluğuna neden olabilirler. Uygulanacak rehabilitasyon dişlerin çekimini, kalan dişlerin post-core restorasyonlar öncesi endodontik tedavilerini, estetik ve fonksiyon amaçlı kron boyu uzatma işlemini ve sabit diş protezlerini içerir. $\mathrm{Bu}$ makalede kliniğimize sevk edilen AI'lı bir hastanın estetik ve fonksiyonel problemlerinin multidispliner tedaviler ile nasıl giderildiği anlatılmaktadır. Restorasyonların uzun dönem başarısı için periyodik kontrollerin yapılması gerekmektedir.

Anahtar kelimeler: amelogenesis imperfecta, estetik, zirkonyum oksit

differences from hypocalcification such as the enamel is harder with a mottled opaque white to yellow-brown or red-brown color, and enamel that is softer than normal that tends to chip from the underlying dentin. In the hypocalcified type, enamel is formed in relatively normal amounts, but the enamel has a very low degree of mineralization. ${ }^{6}$

Additionally, some of dental anomalies have been seen in AI patients such as taurodontism, pulpal calcification, failure of eruption, malformations, root or crown resorption, hypercementosis, and dental and skeletal open bite. ${ }^{7-14}$ Some research also reported that disturbances of the enamel epithilium can cause defects in the eruptive mechanism thus resulting in

*Akdeniz Üniversitesi, Diş Hekimliği Fakültesi, Protetik Diş Tedavisi AD 
anterior open bite. ${ }^{15,16}$ Clinical implications of AI vary according to subtype and its severity, but the main problems are aesthetics, dental sensitivity and loss of vertical dimension and also to increase prevalence of caries, anterior open bite and tooth impaction are seem in some types of AI. ${ }^{16}$ So for the diagnosis these patients must be consultation with relevant departments as orthodontics, periodontal and restorative treatment. ${ }^{17-21}$ In the literature, a lot of cases with different type of AI were reported and all of them were aimed to restore esthetics and function to these patients again. ${ }^{1-22}$ This clinical report describes the interdisciplinary approach for rehabilitating a patient with AI and 4 year follow up.

\section{CASE REPORT}

A 22-year-old man with features of a variant of AI was referred to the department of prosthetic dentistry for oral rehabilitation. The patient was concerned about his appearance and poor masticatory efficiency, which was the result of the destruction of crowns. No abnormalities were diagnosed about medical history. The family history revealed that his parents and brothers were not affected by AI. He was both self-conscious and unhappy as regard the appearance of his teeth.

Firstly, the patient indicated a desire to improve the appearence of his anterior teeth, which were discolored. The patient stated that his maxilla primary teeth were not contact to mandibular primary teeth (Fig. 1A,B,C), but he reported to make the functional habits. An extra oral examination revealed minimal facial asymmetry. Clinical and radiographic examination (Fig. 2) of the patient revealed short clinical crowns, open anterior occlusion, high smile line, healthy gum tissue and deep carious lesions in the maxillary four teeth (right second premolar, right and left first molar and right second molar teeth) and the mandibular left and right second molar teeth. The enamel is harder with a mottled opaque white to yellow-brown. It was concluded that the patient likely suffered from a hypomature type of AI. The patient was informed of the diagnosis treatment procedure, other treatment options, including cost differences, time period for treatment completion, aesthetic results and expected clinical longevity and all treatment plans were discussed with him and his parents. All caries teeth were restored with composite resin and a treatment plan was developed that was restoring masticatory function, improving the aesthetics, reducing the reported tooth sensitivity. The treatment plan included zirconia-based ceramic and metalceramic restorations in maxillary and mandibular anterior and posterior teeth, respectively. It was suggested to extraction $17,27,37,47$ to decrease vertical dimension and eliminate anterior open bite but the patient stated an aesthetics appearance was first request, so anterior open bite was not important for him. After preliminary clinical examination the maxillomandibular relation was recorded. Maxillary and mandibular anterior teeth then were prepared by using medium and coarse diamond burs (Bosphorus, Ann Arbor, Michiga, USA) (Fig. 3). After all crown preparations, complete maxillary and mandibular arch impressions were made using irreversible hydrocolloid (Cavex Holland BV, Haarlem, The Netherlands) for obtaining the diagnostic cast models. Diagnostic casts were fabricated from type III gypsum product (Kalstone; Kalabhai Karson, Mumbai, India] and they were mounted on a semi-adjustable articulator (Stratos 300, Ivoclar Vivadent, Schaan, Liechtenstein) with a face bow transfer (Quick mount face bow; Model 8645, Whip Mix Corp, Louisvlle, USA) and a centric relation record using polyvinylsiloxane occlusal registration material (Vonflex S, Vericom, GangwonDo, Korea). Tooth preparations were finished with a knife-edge finish line with a fine diamond bur (Bosphorus, Ann Arbor, Michiga, USA). The provisional crowns were fabricated and were cemented with zinc oxide eugenol cement (TempBond, Kerr Corp., Orange, CA, USA). After 4 days, complete-arch impressions were made with a polyether impression material (Impregum 3M ESPE, St. Paul, Minn.) for preparing the core materials. From canine to canine in each arch by single crown, frameworks were designed using CAD/CAM from zirconia blocks (IPS e-max ZirCAD, Ivoclar Vivadent, Schaan, Liechtenstein) and porcelain veneering (IPS e.max Press, Ivoclar Vivadent, Schaan, Liechtenstein) was completed according to the manufacturer recommendations. The occlusal and proximal contacts had been adjusted, a trial evaluation of the ceramic material, prior to glazing, enabled final occlusal refinement. The crowns then were cleaned with ultrasound and $70 \%$ alcohol before cementation with dual-cure dental adhesive 
cement (Grandio Core DC, VOCO, Cuxhaven, Germany). For the molar teeth in both of jaw, the both premolar teeth (right and left) and the both molar teeth (right and left) with together were fabricated from each arch by using metal based ceramic and evaluated by intraorally, then cemented with a conventional glass ionomer cements (Meron ${ }^{\circledR}$ (Voco, Germany) using the manufacturer's recommended powder/liquid ratio (Fig. 4A,B,C). After the restorative procedures, the patient was motivated to maintain his oral hygiene and was monitored at 6month intervals for 4 years. The outcome of the treatment in terms of function satisfies the expectations of patient.

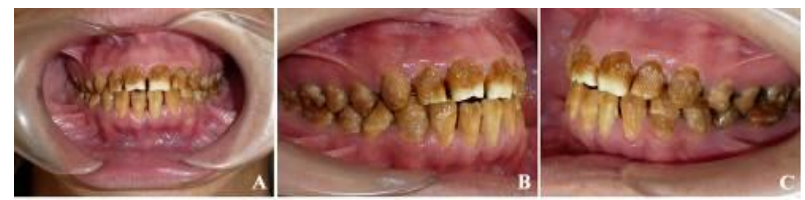

Figure 1. Pretreatment view of the patient. (A) Frontal (B) Right side C) Left side.

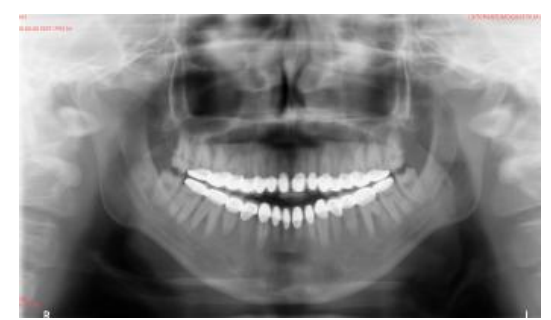

Figure 2. Radiographic views showing restored teeth.

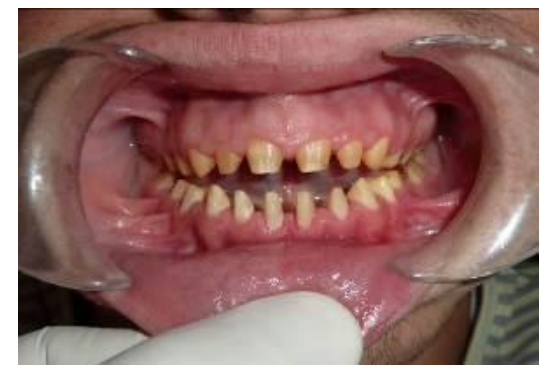

Figure 3. Intraoral view after preparation of the teeth.

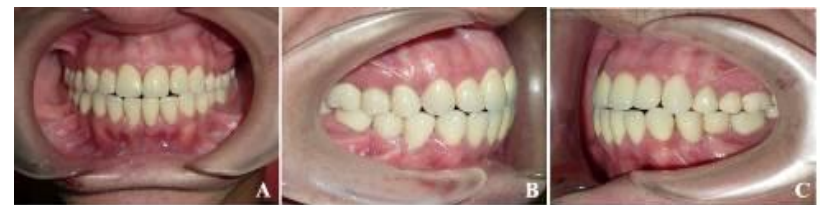

Figure 4. Final restorations. (A) Frontal (B) Right side C) Left side.
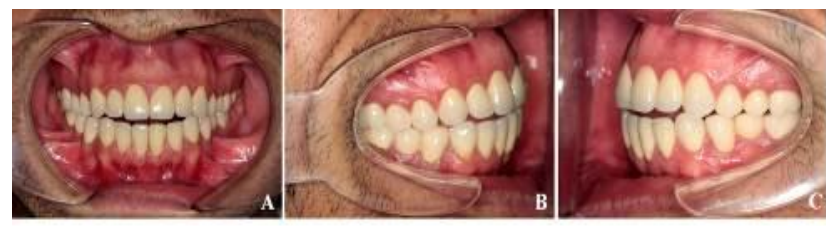

Figure 5.4 years after restorations. (A) Frontal (B) Right side C) Left side.

\section{DISCUSSION}

The restoration of esthetics and function in patients with AI may be achieved with a dedicated team approach. In the literature, a lot of case with AI were reported and all of them were aimed to restore esthetics and function to these patients by use different methods and material. ${ }^{1-22}$ Some researchers advocated that the psychological transformation was spectacular, as was the physiological change and to give a beautiful smile with esthetics materials. ${ }^{15,18,19}$

Treatment planning for patients with AI is related to many factors, including age, socioeconomic status of the patient, the type and severity of the disorder and the intraoral situation at the time that the treatment is planned. ${ }^{3,19}$ When patient requires a comprehensive approach, a mutual understanding and communication among the prosthodontics, endodontic, and periodontics disciplines is very critical, to achieve the improved functional and aesthetic outcome. In this complex rehabilitation, it is essential for the prosthodontics to play a key role in the multidisciplinary team, in supporting both patient and parents. ${ }^{20-24}$ For rehabilitation of patients with $\mathrm{AI}$, several treatment alternatives, with different materials and methods for restorative procedures, are available. Recently, several studies have illustrated the use of over dentures, stainless steel crowns, adhesive casting, composite resin veneers, porcelain veneers, and ceramics for restoring dentitions mutilated by severe attrition. ${ }^{25}$ Besides, the advances in the field of aesthetic dentistry, especially in bonding to dentin, help practitioners to restore function and aesthetics to an acceptable level. ${ }^{26}$ The clinician must carefully balance the aesthetic needs of the patient, strength of the restoration, protection of remaining teeth, and longterm prognosis of the treatment. ${ }^{6}$ Marginal fit and color acceptability of the restorations were satisfactory in our case, that improved the patient's selfconfidence. This treatment option, however, requires

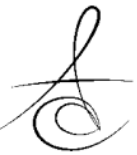


a meticulous oral hygiene practice. This clinical report describes the use of zirconia based ceramic and metalceramic restorations for rehabilitation of a patient with hypomaturation type of AI.

After for 4 years, the panoramic radiograph revealed that four impacted third molar teeth in both jaws eruptioned, so in clinically the amount of the anterior open bite was observed to be increased (Fig. $5 A, B, C)$. The reasons of this problem might be related to several factors including (1) the eruption of the third molars and the potential mesialization effects of those teeth, (2) the problems of tongue positions during swallowing and rest, ${ }^{27}$ and (3) the possible change of the condyle in the glenoid fossa. It has been suggested that all third molar teeth should be extracted and posterior restorations should be fabricated again. Exercising the patient swallowing muscles is the best way to improve his ability to swallow, so it should be suggested and last one, if a patient has a temporomandibular disorder (TMD) prior to the prosthetics therapy, his-her management's TMD joint therapy should be firstly done. ${ }^{28,29}$ However, the patients did not agree with our treatment choice because of this condition did not affect to quality of his life as aesthetic and functional rehabilitations. The patient's oral hygiene was satisfactory because of the healthy gingiva was present around the all restored teeth and there were not periapical inflammatory changes to all restored teeth.

The restoration of aesthetics and function in patients with AI can be achieved by making an accurate diagnosis, meticulous treatment planning, together with a dedicated team approach involving different disciplines in dentistry. Further use of modern ceramic materials such as zirconia and adhesive bonding and a justifiable reliance on the predictable artistic abilities of the dental technologist, allow both aesthetic and durable restorations.

\section{CONCLUSION}

For the AI patients, the rehabilitation included anterior and posterior restorations with aesthetics material to eliminate tooth sensitivity improve the aesthetics and occlusion, good psychology changes and restore function. Additionally use of modern ceramic materials such as zirconia and adhesive bonding and a reliable reliance on the predictable artistic abilities of the dental technologist, allow both aesthetic and durable restorations. It has been suggested that AI patients must be monitored at 6month intervals for ensuring long-term success to the restorations.

\section{REFERENCES}

1. Paula LM, Melo NS, Silva Guerra EN, Mestrinho DH, Acevedo AC. Case report of a rare syndrome associating amelogenesis imperfecta and nephrocalcinosis in a consanguineous family. Arch Oral Biol 2005;50:237-42.

2. Hart TC, Hart PS, Gorry MC, Michalec MD, Ryu OH, Uygur C, Ozdemir D, Firatli S, Aren G, Firatli E. Novel ENAM mutation responsible for autosomal recessive amelogenesis imperfecta and localised enamel defects. J Med Genet 2003;40:900-6.

3. Chamarthi V, Varma BR, Jayanthi M. Amelogenesis imperfecta: A clinician's challenge. J Indian Soc Pedod Prev Dent 2012;30:70-3.

4. Koroglu A, Ekren O, Kurtoglu C. Prosthtethic rehabilitation of patients with different types of amelogenesis imperfecta . J Dent Fac Ataturk Uni 2012;5:34-9.

5. Yildiz M, Duran E. Amelogenesis imperfecta and application of modifiy $\mathrm{mc}$ innses method. J Dent Fac Ataturk Uni 1997;7:89-91.

6. Sari T, Usumez A. Restoring function and esthetics in a patient with amelogenesis imperfecta: a clinical report. J Prosthet Dent 2003;90:522-5.

7. Atasu M, Biren S, Mumcu G. Hypocalcification type amelogenesis imperfecta in permanent dentition in association with heavily worn primary teeth, gingival hyperplasia, hypodontia and impacted teeth. J Clin Pediatr Dent 1999;23:117-21.

8. Collins MA, Mauriello SM, Tyndall DA, Wright JT. Dental anomalies associated with amelogenesis imperfecta: a radiographic assessment. Oral Surg Oral Med Oral Pathol Oral Radiol Endod 1999;88:358-64.

9. Korbmacher HM, Lemke R, Kahl-Nieke B. Progressive pre-eruptive crown resorption in autosomal recessive generalized hypoplastic amelogenesis imperfecta. Oral Surg Oral Med Oral Pathol Oral Radiol Endod 2007;104:540-4. 
10. Ooya K, Nalbandian J, Noikura T. Autosomal recessive rough hypoplastic amelogenesis imperfecta. A case report with clinical, light microscopic, radiographic, and electron microscopic observations. Oral Surg Oral Med Oral Pathol 1988;65:449-58.

11. Ravassipour DB, Powell CM, Phillips CL, Hart PS, Hart TC, Boyd C, Wright JT. Variation in dental and skeletal open bite malocclusion in humans with amelogenesis imperfecta. Arch Oral Biol 2005;50:611-23.

12. Seow WK. Dental development in amelogenesis imperfecta: a controlled study. Pediatr Dent 1995;17:26-30.

13. Seymen F, Kiziltan B. Amelogenesis imperfecta: a scanning electron microscopic and histopathologic study. J Clin Pediatr Dent 2002;26:327-35.

14. Bäckman B, Holm AK. Amelogenesis imperfecta: prevalence and incidence in a northern Swedish county. Community Dent Oral Epidemiol 1986;14:43-7.

15. Backman B, Adolfsson U. Craniofacial structure related to inheritance pattern in amelogenesis imperfecta. Am J Orthod Dentofacial Orthop 1994;105:575-82.

16. Weinmann JP, Svoboda JF, Woods RW. Hereditary disturbances of enamel formation and calcification. J Am Dent Assoc 1945;32:397-418.

17. Doruk C, Ozturk F, Sari F, Turgut M. Restoring Function and Aesthetics in a Class II Division 1 Patient with Amelogenesis Imperfecta: A Clinical Report. Eur J Dent 2011;5:220-8.

18. Neville BW, Douglass DD, Allen CM, Bouquot JE. Oral and Maxillofacial Pathology. Philadelphia (PA): Elsevier; 2004;89-94.

19. Suchancova B, Holly D, Janska M, Stebel J, Lysy J, Thurzo A, Sasinek S. Amelogenesis imperfecta and the treatment plan- interdisciplinary team approach. Bratisl Lek Listy 2004;115:44-8.

20. Halicioglu K, Karaalioglu OF, Kiliç N, Oktay $H$. Interdisciplinary treatment of amelogenesis imperfecta: a case report. J Dent Fac Ataturk Uni 2011;21:125-8.

21. Rajesh P, Prasad M, Haldal S. Full Mouth Rehabilitation of a patient with amelogenesis imperfecta: a case report. Journal of International Oral Health 2014;6:76-9.
22. Yilmaz B, Oz U, Yilmaz HG. Interdisciplinary approach to oral rehabilitation of patient with amelogenesis imperfecta. The New York State Dental Journal 2014;82:31-5.

23. Ozturk N, Sari Z, Ozturk B. An interdisciplinary approach for restoring function and esthetics in a patient with amelogenesis imperfecta and malocclusion: a clinical report. Journal of Prosthetic Dentistry 2004;92:112-5.

24. Akin $H$, Tasveren S, Yeler DY. Interdisciplinary approach to treating a patient with amelogenesis imperfecta: a clinical report. J Esthet Restor Dent 2007;19:131-5.

25. Paine $M L$, White $S N$, Luo $W$, Fong $H$, Sarikaya $M$, Snead ML. Regulated expression dictates enamel structure and tooth function (review). Matrix Biol 2001;20:273-92.

26. Sockalingam S. Dental rehabilitation of amelogenesis imperfecta using thermoformed templates. J Indian Soc Pedod Prev Dent 2011;29:53-61.

27. Winter GB. Amelogenesis imperfecta with enamel opacities and taurodontism: An alternative diagnosis for 'idiopathic dental fluorosis' Br Dent J. 1996;181:167-72.

28. Khodaeian N, Sabouhi M, Ataei E. An interdisciplinary approach for rehabilitating a patient with amelogenesis imperfecta: a case report. Case Rep Dent 2012;2012:1-8.

29. Rowley R, Hill FJ, Winter GB. An investigation of the association between anterior open-bite and amelogenesis imperfecta. Am J Orthod 1982;81:229-35.
Yazışma Adresi
Dr. Ömer Kirmali
Akdeniz Üniversitesi,
Diş Hekimliği Fakültesi, Protetik Diş Tedavisi AD
Antalya, Türkiye.
Tel: +90 242 2274400-2935,
Fax: +90 2423106967 ,
e-mail: omerkrml@ymail.com 